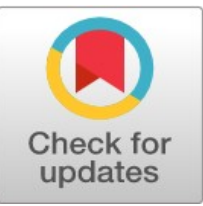

PRIMARY RESEARCH

\title{
The impact of China-Central Asia relations on Xinjiang Uyghur Muslim riots
}

\author{
Liang Qianli
}

\author{
Thammasat University, Bangkok, Thailand
}

\author{
Keywords: \\ China \\ Central Asia \\ Uyghur Muslim riots \\ Three evil forces \\ East Turkestan forces \\ SCO \\ Institutionalism \\ Constructivism
}

Received: 26 March 2016

Accepted: 30 March 2016

Published: 26 April 2016

\begin{abstract}
This paper focuses on two objectives: to explore why Xinjiang Uyghur Muslim uprisings got motivated, and the other is to assess whether the closer China-Central Asia co-operations help ease the tension. Moreover, this research attempts to investigate the other external players involved in the Uyghur turmoil. The study employed the qualitative method to analyze how Sino-Central Asia relations play a role in countering East Turkistan forces and ease the Xinjiang tension. The analysis and argument are based on the institutionalism of Neo-liberalism to examine the impacts of China's foreign policies towards Central Asia, especially the institute of Shanghai Cooperation Organization (SCO), as well as the constructivism theory to analyze the norms. These ideas shape the political attitudes of external players on the Xinjiang issue. This paper argued that to prevent the further sprawl of the East Turkestan forces and maintain regional stability and peace, China would continue to work with Central Asian countries in terms of counter-three evil forces through the SCO. The research explored the development and challenges that SCO will face and analyzed its impacts on the solution of Xinjiang Uyghur Muslim riots shortly.
\end{abstract}

(C) 2016 The Author(s). Published by TAF Publishing.

\section{INTRODUCTION}

\section{The Impact of China-Central Asia Relations on Xinjiang Uyghur Muslim Riots}

On July 28, 2014, a violent terrorist attack conducted by a gang of thugs who targeted the Ailixihuzhen local government and police office with ax happened in Yarkand in Kashgar area of Xinjiang Uyghur Autonomous Region (XUAR), causing two Uyghur Muslims and 35 innocent Han people to die, and 13 people were injured. Meanwhile, there were 31 vehicles smashed, including 6 cars burned. Coincidently, that day was the Feast of Breaking the Fast. So critics considered that the deliberate and well-organized action aimed at destabilizing the region, spreading terrorism atmosphere and inciting ethnic hatred by connecting religion and ethnic issue. While two days later, Jume Tahir, chief imam of Kashgar's Id Kah Mosque was assassinated by three mobs who were influenced by religious extremism after he finished Al Fajr (morning call to prayer). Since serious Uyghur Muslim uprisings occurred on July 5th, 2009,

\footnotetext{
* Corresponding author: Liang Qianli

E-mail: bambinia00@gmail.com
}

The Author(s). Published by TAF Publishing. This is an Open Access article distributed under a Creative Commons AttributionNonCommercialNoDerivatives 4.0 International License 
leaving about 200 people dead and more than a thousand injured according to Chinese government release, the continuity of the violent attacks on civilians of Kunming, Guangzhou, and Beijing in recent years has been observed.

However, similar violence between different ethnicities based on different religious beliefs, especially in the Islamic world, happened almost every day. For instance, in Southeast Asia, disputes between Rohingya ethnic Muslims and Buddhists living in western Myanmar always jangle peoples' nerves. And it is very common to see reports published on various media pointing out that there are bombs blasting and bleeding incidents in deep south of Thailand. Hence, Uyghur Muslim violence is not a sole ethnic problem troubling the Chinese authority.

Xinjiang Uyghur Muslim riots occurred with many reasons, while the three evil forces: terrorism, separatism and extremism, are the primary factors behind these violent attacks, since the three evil forces have existed in China and Central Asia for a very long time. How to counter these forces needs every state in the region to cooperate without skepticism. Since there are many different and similar status quos between China and Central Asian states, the relations of the two sides will inevitably influence the cooperation level and eventually function on the solution of Xinjiang Uyghur Muslim riots.

In the paper, author wants to study the evolution of Sino-Central Asia relations, to analyze the causes of Xinjiang Uyghur Muslim riots, as well as show the anti-terror achievements and challenges of the SCO, a key multilateral cooperation institute between China and Central Asian states, and its impact on resolving the uprisings. However, the paper will focus more on the transboundary factors influencing the settlement of Xinjiang issue instead of China's domestic policy recommendations. Meanwhile, as the trend of Xinjiang Uyghur Muslim riots is changing with the international Islamic movement, author could only analyze what happened before, and give the possible predictions on the future of China-Central Asia cooperation on anti-terror. When confronted with the new situation, both China and Central Asian states have to consider more carefully and come up with the corresponding measures. In addition, though the SCO has been set up for 15 years since 2001, it is still a very young international organization compared with other institutes in Central Asia. So its regimes and norms are just relatively completed, with large room for further improvement. That's why the research on the security cooperation among the SCO member states and relative shareholders has certain limitations. Furthermore, the policy implementation in several states should also be considered if China wants to fully eradicate the Xinjiang problem.

\section{LITERATURE REVIEW}

\section{Literature on the Origin of Xinjiang Uyghur Muslim Riots}

As Andrew D. W. Forbes observed in his book Warlords and Muslims in Chinese Central Asia: A political history of Republican Sinkiang 1911-1949, "The Soviet Union supported the Uyghur Second East Turkestan Republic (USETP) in the Ili Rebellion against the Republic of China. Many of the Turkish people of the Ili region of Xinjiang had close cultural, political, and economic ties with the Russian Empire and then the Soviet Union (Forbes, 1986)."

Besides, Uyghur activist Rebiya Kadeer remembered in her autobiography: Dragon Fighter: One Woman's Epic Struggle for Peace with China that her father 
served with pro-Soviet Uyghur rebels under the Second East Turkestan Republic (SETR) in the Ili Rebellion (Three Province Rebellion) in 1944-1946, using Soviet assistance and aid to fight the Republic of China government under Chiang Kai-shek (Kadeer \& Alexandra, 2009).

Yitzhak Shichor in his article The Great Wall of Steel: Military and Strategy reveals that, "The Soviet Union intensified their support in 1967, doubling their Uyghur language broadcasts, and broadcasting Radio Tashkent, which encouraged Uyghurs to revolt against the Chinese. Separatist fighters were harbored by the Soviets, and it is estimated that 5,000 soldiers launched attacks on China via the Sino-Soviet border in 1966 (Millward et al., 2004)."

Ablet Kamalov also believes in his article The Uyghurs as a Part of Central Asian Commonality: Soviet Historiography on the Uyghurs that, "The Soviet Union supported Uyghur nationalist propaganda and Uyghur separatist movements against China. Soviet turcologists like D.I. Tikhonov wrote proindependence works on Uyghur history and the Soviet supported Uyghur historian Tursun Rakhimov who wrote more historical works supporting Uyghur independence and attacking the Chinese government, claiming that Xinjiang was an entity created by China made out of the different parts of East Turkestan and Zungharia. These Soviet Uyghur historians were waging an "ideological war" against China, emphasizing the "national liberation movement" of Uyghurs throughout history (Bellér-Hann, 2007)."

As many Chinese Scholars' works and Chinese government official White Book on History and Development of Xinjiang indicates that, "In the early 20th century and later, a small number of separatists and religious extremists in Xinjiang, influenced by the international trend of religious extremism and national chauvinism, politicized the unspecialized geographical term "East Turkestan," and fabricated an "ideological and theoretical system" on the socalled "independence of East Turkestan" on the basis of the allegation cooked up by the old colonialists (Information Office of the State Council of the People's Republic of China [IOSCPRC], 2003)."

As Lai Hongyi says that, "Southern Xinjiang, as well as Yining in the western part of the region, have severe unemployment and other economic problems and these areas appear to be hotbeds of such activities (refer to the Uyghur Muslim unrests) (Lai, 2002)."

\section{Literature on China-Central Asia Relations}

Zhao Huasheng argues that, "China's economic interests in Central Asia are insignificant in terms of explaining Chinese interest in the region, while its role in guaranteeing the stability and economic development of Xinjiang and thus the territorial integrity of China is essential. Furthermore, he says that the logic behind the Chinese presence in Central Asia is inherently led by domestic pressures, particularly with regard to security needs (Zhao, 2007)."

Prominent Kazakhstani sinologist Konstantin Syroyezhkin says that, Central Asia is seen by China as a "strategic rear," since the problems that take place in the region have significant impact on one of China's Achilles' heels: Xinjiang (Tukmadiyeva, 2013).

Shen Wei and Weng Cuifeng wrote in their journal of China's New Policy in Xinjiang and its Challenges, "China's concern over Uyghur ethnic separatism in Xinjiang has pushed it to increase the pace of development in what is its largest 
region, yet remains one of its poorest. China's aspirations of "leapfrog development" and "long-term stability" in Xinjiang are likely to result in respective "leapfrog" increases of Chinese presence in Central Asia (Shan and Weng, 2010)."

Furthermore, Xing Guangcheng argued that, "to a large extent the stability and prosperity of Northwest China is closely bound up with the stability and prosperity in Central Asia (McMillan, 2009)."

\section{METHOD}

This paper intends to apply a qualitative method of research to analyze that how China-Central Asia relations play a role in the process of countering East Turkestan force and ease the Xinjiang tension. It is about to be based on indepth analysis of primary and secondary data. The primary resources will be collected through several elite interviews of experts and commentary reporters on Xinjiang Uyghur minority ethnic issue, while the secondary data will be carefully selected from speeches of Chinese leaders, Central Asian states' leaders, professors, policy statements, books, journals, theses, press releases.

\section{The Causes of Xinjiang Uyghur Muslim Riots}

It is essential to understand the complexity of Xinjiang Uyghur Muslim riots, which contain the interactive impact of historical and realistic factors, secular and religious factors, economic and political factors, ethnic cultural difference, geographical factors etc. Before digging the reasons why the riots are motivated, author believes that it is more significant to figure out the different backgrounds in distinct era. To view the outbreak of riots in the early 20th century, author will concern more about the background of warlord period and the Soviet Union's influence, rather than Islamic identification. While observing the resurgence of Uyghur Muslim unrest in the early 21st century, author will pay more attention to the unjust distribution of economic resources in Xinjiang between Uyghurs and Han conducted by the Communist Party of China (CPC) and the international counter-terrorism's influence in the process of globalization.

\section{Overseas Supports}

For tracing the source, the formation and development of the East Turkestan forces are closely connected with the invasion of imperialist powers after the Opium War and the US-led western powers' supports for curbing China's peaceful rise during the post-Cold War period. Modern China's weak national strength provided chance for the so-called western and eastern advanced powers to interfere with Xinjiang and Tibet issues.

The Soviet Union: The Soviet Union's Xinjiang strategy changed based on how to maximize its benefits. In 1933, the United Kingdom endorsed the East Turkestan Independence Association led by Sabit Damolla to establish the first East Turkestan Republic (ETR) in southern Xinjiang, Kashgar city in particular. At that time, there were fierce battles between Xinjiang warlord Sheng Shicai backed by the Soviet Union and Ma Zhongying based in Gansu province and supported by Japan. However, defeated by Sheng Shicai, Ma Zhongying then retreated to southern Xinjiang and routed the ETR with only a slight effort. Finally, with the great support of the Soviet Red Army, Sheng Shicai eradicated the remnants of Ma Zhongying in the south, which led to many main leaders of 
the ETR to fleeS abroad. Although the ETR had only existed for three months, it was for the first time that East Turkestan forces tried to build a "state", which leveraged ethnic split credential and it was also the beginning of the East Turkestan independence movement. This ethnic-separatism history has been inherited by Xinjiang ethnic separatists so far.

Before Sheng Shicai fell out with the Soviet Union, the Soviet Union developed its own forces vigorously in Xinjiang and even pursued the northern Xinjiang Independence. The failure of communist ideology propaganda in Xinjiang urged the Soviet Union later to take advantage of anti-Han sentiment among local ethnic minorities, Islam belief and the theory of Pan-Turkism to achieve a goal of controlling Xinjiang or creating a "second Mongolia".

By 1946, East Turkestan national army commanded by Ivan J. Polinov (Russian) hit the Manas River located in the west of Dihua (modern Urumqi) with strong tanks, artilleries and cavalries given by the Soviet Union. Xinjiang was about to be a new republic of the Soviet Union. However, East Turkestan Revolution Organization, the political wing of the national army was an alliance composed of local Bolshevik ethnic groups, Muslim nationalism groups and PanTurkism forces. During the period of 'the revolution against the oppression of capitalists in Xinjiang', the Soviet Union was concerned that once the power of Pan-Turkism and Pan-Islamism became strong enough, it was very likely to influence the similar forces existing in the Central Asian republics, leaving a seriously negative aftermath on the Soviet Union's control of Central Asia. Thus the Soviet Union adjusted its policies to recognize Chinese sovereignty over Xinjiang by calling for the establishment of a highly organized "autonomy" region, as the joint ethnic army (national army) was a fait accompli. The national army became a bargaining chip of the Soviet Union to "negotiate" with Chiang Kai-shek government for ensuring its vested interests. After its interests guaranteed by the Sino-Soviet Treaty of Friendship and Alliance, the Soviet Union agreed to mediate the conflict in Xinjiang and prevent "Xinjiang Independence".

Until the People's Republic of China (PRC)'s establishment, the Ili Rebellion was identified as Three Districts Revolution (revolution against capitalists), while the Xinjiang national army gradually dissolved or incorporated into the People's Liberation Army (PLA). Obviously, though the Soviet Union's ambition to challenge China's sovereignty in Xinjiang had decreased, its actual influence in Xinjiang society was not eliminated. Since many of these Soviet residents actively participated in the Three Regions Revolution, they worked as officers in China's political party, provincial government and army in Xinjiang. It is very abnormal to see a large proportion of Soviet residents serving as officers in China.

In the early 1960s, the deterioration of Sino-Soviet relations drove the Soviet Union to instigate separatist activities in Xinjiang region again. It set up training centers in Talas of Kazakhstan and Samarkand of Uzbekistan to train Uygur, Kazak refugees fleeing from China to be agents, then dispatched them back to China to steal information and incite separatist activities. Meanwhile, it printed materials and set radio stations to broadcast ethnic separatism content via Uyghur language. The radio station was not withdrawn until 1985. On April 22, 1962, more than 60,000 Xinjiang residents left China for the Soviet Union, even including two major generals of Xinjiang military command. The Chinese central 
government believed that the Soviet Union embassy in Ili plotted the so-called Yita Event. In addition, in the year of 1969, the Soviet Union and China had a conflict on Damansky island (or Zhenbao island) in March and a bloodshed in Tielieketi of Xinjiang in August.

In 1970s, the Sino-Soviet relation was of hostility and mistrust. Mao Zedong, then chairman of the CPC called on opposing the domination of the first world which included the United States (US) and the Soviet Union. Besides, the Soviet Union's invasion of Afghanistan at the end of 1979 also caused China's strong opposition. It was until the early 1980s that the decades of hostility between China and the Soviet Union ended. In response, China sponsored Afghanistan legal government to go against the Soviet Union. According to Chinese release, 19 revolts and 194 cases occurred in Xinjiang from 1951 to 1981 mostly supported by the Soviet.

The US: Besides the Soviet Union, now western countries led by the US preferred to support East Turkestan forces from a view of human right. Some US government-related scholars attempted to legalize "Xinjiang Independence" by criticizing the China's legal authority in Xinjiang as a relation of suzerain (Han) and settlers (Uyghur), provoking the relationship between Han and local ethnic minorities, and imposing western values on Chinese authority.

In the 1990s, the Uyghur American Association was founded in Washington, which further strengthened the power of East Turkestan separatist forces in US. Rebiya Kadeer was released on bail for medical service on March 17, 2005 and she directly fled to the US with 17 months of her term sentence unexecuted. A year after, she was "elected" to be the chairwoman of the World Uyghur Congress (WUC) and strengthened the propaganda of East Turkestan Independence by plotting and instigating several terrorist attacks. This socalled 'exiled group' is literally sitting in Washington D.C., funded by the US State Department, and serving the convenient role of destabilizing China, widely acknowledged by the US itself as an adversary (Cartalucci, 2015). After the July 2009 Urumqi riots, US Congressman McGovern said, "The PRC has violated internationally recognized human rights and legal due process standards by carrying out executions after trials marred by procedural abuses and by carrying out arbitrary detentions targeting Uyghurs and other individuals in Xinjiang in the aftermath of a suppressed demonstration and ensuing mob violence from July 5 to 7, 2009 (McGovern, 2009)."

The US's supports for the WUC could be explained in the way of constructivism. According to Alexander Wendt, "Our mental maps are shaped by collectively held ideas such as knowledge, symbols, language, and rules. Idealism does not reject material reality but instead observes that the meaning and construction of that material reality is dependent on ideas and interpretation (Wendt, 1999)." In this sense, scholars and governments consider Xinjiang issue with their own background and culture. It is universally known that the ideologies of China and the US holding in their state's governance are completely different. China is a socialist state, while the US is a capitalist state. Moreover, China and the US generally hold different emphasis on social values. So are the understanding of democracy and the relations between sovereignty and human rights. It results in different views on the issue of the fighting against terrorism between the US and China. That's why the WUC is identified as one of the main terrorist organizations by Chinese government 
but gains a lot of support from the US. This phenomenon well shows that the world is constructed by ideas and material reality.

However, Xinjiang issue is still unlikely to be the US's main focus currently. Similarly, the US hopes the East Turkestan separatism force led by Kadeer to increase media exposure and expand its influence. As author predicted, the US would not like the peaceful settlement of Xinjiang issue, because it can make troubles for Chinese government, eventually curbing the rapid rise of China.

Turkey: Turkish successive governments normally showed two distinct attitudes to East Turkestan forces. Some administrations would like to cooperate with Chinese government to constrain East Turkestan forces, but sometimes they feel sympathy and provide support for those Xinjiang separatists. When the violent change of the Soviet Union and Eastern Europe in the early 1990s took place, senior Turkish officials publicly met leaders of East Turkestan forces. But a few years later, Turkish government seldom gave speeches on support of Pan-Turkism but turned to criticize China's ethnic minority policies.

Currently, there are 20 groups advocating the East Turkestan separatism in Turkey. On the foreign policy front, Turkey has been proactive in participating in regional affairs, and has used cultural links and business ties to strengthen cooperation between Turkic-speaking countries. Some Turkish politicians have long aspired for a "Turkic Union" with Azerbaijan, Kazakhstan, Turkmenistan, Uzbekistan and Kyrgyzstan, and the Turkish government has made Turkic people and Muslims their priority when making policies. In addition, the Turkish government has an open attitude toward immigrants, whether they have arrived in the country legally or illegally ("Some Uyghurs travel to Turkey", 2015). The loose immigration policy under the Turkish government attracts some Uyghur Muslim in Xinjiang to leave China legally and illegally. And it was also true that a small group of Uyghur Muslims became terrorists to jihad in Syria and Afghanistan after they were lured by East Turkestan extreme groups, such as East Turkestan Education and Mutual Assistance Association.

\section{Pan-Islamism and Pan-Turkism}

The unrest in Xinjiang over the past decades has a close relationship with the penetration of Pan-Islamism and Pan-Turkism there. The ideologies of PanTurkism and Pan-Islamism were introduced into Xinjiang from the early 20th century.

Pan-Islamism: Pan-Islamism was raised by Jamal ad-Din al-Afghani during the middle of the 19th century, with its core ideology of uniting all Islamic countries to establish a unified Islamic political entity under the rule of a strong Caliphate.

Before studying the above Pan-Islamism, it will be better to understand the classification of the Xinjiang local Muslims. After Islam is introduced in Xinjiang and becomes popular among Uyghurs, there are 4 types of Muslims including cultural Muslim, secular Muslim, conservative Muslim and Muslim extremist based on the degree of Muslim secularization in Xinjiang. Cultural Muslim seldom participates in religious activities, and usually does not avoid smoking and alcohol. But they still follow some traditional customs; Secular Muslim joins in more religious activities, such as fasting, as they keep the belief in Islam and follow their ancestral traditions; Conservative Muslim, or Wahhabism follower promotes simple life, resists waste and seeks for inner peace and stability. But 
this group normally does not advocate violence or has any political aspirations; Muslim Extremist, or Political Muslim, is evolved from conservative Muslim, regarded as religious reformer with obvious political demands, such as the establishment of the theocracy in Xinjiang.

Wahhabism: Wahhabism is one school of Modern Islamic revivalism. It was introduced into Kumul region of Xinjiang in the 1980s. Wahhabism followers and Muslim extremists are very likely to become terrorists compared with cultural Muslims and secular Muslims in Xinjiang because the negative factors of Wahhabism include different interpretations of the classic Islam, which confuses followers and damages local traditional culture and customs. As every preacher has his own understanding of Al Quran, which can be formed with the references to Iran, or Saudi Arabia, or Egypt, or Afghanistan etc., so believers can easily feel confused. If Wahhabism followers seek for clear political appealing, like Xinjiang independence, Islamic state etc., they will be recognized as separatists and religious extremists according to the China's anti-terror law. The most prestigious political Muslims in Xinjiang are Ablikim Mahsum and his 800 followers.

Hizb ut-Tahrir: It is also known as Islamic Liberation Party (ILP), a radical, international, Pan-Islamic political organization. The party mission is the reestablishment of "the Islamic Khilafah (Caliphate)" or Islamic state, ruled by Islamic Shariah law by non-violence method. It entered Central Asia in the early 1990s, later spreading to Xinjiang. The ILP in Xinjiang has about 20,000 members aiming at advocating separatism (News Week, 2009). However, the ILP in Central Asia and Xinjiang are featured with violence and terrorism. It incited Uyghur people to go against the legal government and seek for "Xinjiang independence". Its members comprise of education workers, religious figures, individual craftsmen in the bottom level of society, released people, ethnic minority women and minors. Gheyret Niyaz, a Uyghur journalist observed that the July 2009 Urumqi riots were planned and conducted by the ILP in Xinjiang, as he heard the mob shouting the slogan of the establishment of Islamic Caliphate.

Hejira Jihad: Shukri Mustafa appealed to Muslims to practice their religion by migration, ignoring the limitation of the state border. He asked Muslims to pursue Jihad in the Ummah where people had the same Islamic faith. Currently, many Uyghur Muslims in Xinjiang are motivated by the above theory and decide to go for jihad by the way of migration. According to the cases of people smuggling investigated by the police, there are mainly two routes that the illegal immigration brokers normally organize for illegal Muslim migration. The first one is Xinjiang-Central Asia-Afghanistan/Syria/Iraq, while the second one is Xinjiang-China's southern provinces (Guangdong/Guangxi/Yunnan)-Southeast Asia-Turkey-Syria/Iraq/Afghanistan. While the second route has been favored by the migration jihadists in the past 5 years, it is for the closer cooperation between China and Central Asia on cracking down non-traditional security that the first route has been less popular or secure among those migration jihadists. If they choose the first route, they will be discovered by Chinese police easily in the context of the past decades' crackdown on three evil forces, which means that they are faced with many obstacles in crossing the borderline between Xinjiang and Central Asia. Even if they flee to Central Asia by a fluke, they are 
very likely to be arrested, then repatriated by the police of Central Asian states who work closely with China on counter-terrorism issues.

Pan-Turkism: It is an ideological trend created by the Russian Tatar intelligentsia during the 19th century. It initially advocates to unite all the Turkic-speaking ethnics to set up a "Turkic nation" in order to resist the rule of Russian Kingdom. As the birthplaces of all Turkic people should be considered as "Turks' native lands", the Soviet Union scholars take Central Asia of the Soviet Union as West Turkestan, and regard the Xinjiang region of China as East Turkestan. Since then, East Turkestan is rather a geographical concept but a political concept.

The first seeds of modern Turkic nationalism in Xinjiang were planted around the beginning of the 20th century in the Kashgar and Yining (Gulja) areas. Uyghur capitalists who had traveled to Germany, Turkey, and Russia found their homeland to be backward by comparison. Deeply influenced by liberal Tatar and Turkish intellectuals, they sought to implement modern education among the Turkic people in Xinjiang (Millward \& Perdue, 2004). The most recent and dangerous terrorist organization is East Turkestan Islamic Movement (ETIM). From the 1990s to the early 2000s, the ETIM planned and conducted a number of violent attacks in Xinjiang and neighboring Central Asian countries. It was founded outside China by Hasan Mahsum and other separatists with an initial goal of building an Islamic state in Xinjiang. But then a further escalation of its goal was to eventually establish a unified pan-Turkestan Islamic state covering the entire Asia Minor and Central Asia. In fact, after the end of the Cold War, the scale of the ETIM and its allied groups had reached unprecedented new heights, which increasingly became a major threat to the Chinese government.

\section{Economic Condition}

If a citizen cannot get what he or she demands as a human being, such as reasonable economic opportunities, he or she is more likely to be frustrated in society and expresses his or her dissatisfaction by either peaceful or violent method. Since Chinese central government started carrying out the policy of reformation and opening nationwide, the wealth gap between Xinjiang and the inland areas widened dramatically. Deng Xiaoping's economic strategy is to achieve common prosperity by allowing some people to get rich first, then the rich leads the poor. The reality of Xinjiang at that time was that a small group of ethnic minorities indeed became rich encouraged by the country's reform and opening up policies, leaving the living standard and quality for the majority of ethnic minorities and Han people were much lower than the rich mentioned above. Geographically, because the natural conditions of northern Xinjiang are better than the southern part, Xinjiang government emphasized more on the development of northern part in the past decades and relatively neglected the development of the Muslim-populated southern Xinjiang.

According to data collected by the Ministry of Public Security, several riots occurred in Urumqi were conducted or participated by those unemployed Uyghur youth from southern Xinjiang. Southern Xinjiang refers to Kashgar Prefecture, Hotan Prefecture, Aksu Prefecture and the Kirgiz Autonomous Prefecture, that accounts for one-third of Xinjiang territory. But over $90 \%$ of southern Xinjiang territory are Gobi deserts and mountains, leaving a very small part of land that can be used as cultivation area. Influenced and restricted by 
nature, socio-cultural history and other factors, the economic and social development level of ecologically fragile southern Xinjiang lags behind northern part significantly. Statistics show that, because the scale of second and third industries in southern Xinjiang are rather small for a very long time, there are less employment opportunities except for being farmers. The number of surplus labors in four prefectures of southern Xinjiang is above 1.5 million, or $60 \%$ of the total surplus labors in Xinjiang. Furthermore, there are 1.59 million of the population identified as poor people in accordance with the national poverty standard of 2014 (RMB:2800 Yuan) in southern Xinjiang, or over $80 \%$ of the impoverished population in Xinjiang. One thing that has to be clear is that Uyghur Muslims are distributed mainly over four prefectures of southern Xinjiang. According to Table 1, those data can explain that poverty of southern Xinjiang represents the very low living standard of Uyghurs there, in accordance with the data above.

TABLE 1. Uyghur population data in four prefectures of Southern Xinjiang (2012)

\begin{tabular}{lccc}
\hline \hline Prefecture & Uyghur & Total & Percentage of Total Population \\
\hline Aksu & $1,888,881$ & $2,396,877$ & $78.81 \%$ \\
\hline Kirgiz & 360,792 & 560,627 & $64.36 \%$ \\
\hline Kashgar & $3,803,463$ & $4,151,345$ & $91.62 \%$ \\
\hline Hotan & $2,044,223$ & $2,123,377$ & $96.27 \%$ \\
\hline \hline
\end{tabular}

Source: (Statistic Bureau of Xinjiang Uygur Autonomous Region [SBXUA], 2012)

Furthermore, according to Table 2, the per capita annual income gap between urban residents and rural residents in four southern prefectures of Xinjiang is so big. The per capita annual income of urban residents in Aksu is the highest among the four prefectures, reaching 20049 yuan, but still ranks 6th out of 14 cities and prefectures in the XUAR. The per capita annual income of rural residents in Aksu is also the highest among the four prefectures, reaching 7875 yuan, but ranks 9th of 14 cities and prefectures. Moreover, compared with the advantage data of China in the year of 2013, 7 out of 13 cities and prefectures in the XUAR do not reach the national average of per capita annual income of rural residents, including 4 prefectures in southern Xinjiang with very big gaps respectively.

Furthermore, according to Table 2, the per capita annual income gap between urban residents and rural residents in four southern prefectures of Xinjiang is so big. The per capita annual income of urban residents in Aksu is the highest among the four prefectures, reaching 20049 yuan, but still ranks 6th out of 14 cities and prefectures in the XUAR. The per capita annual income of rural residents in Aksu is also the highest among the four prefectures, reaching 7875 yuan, but ranks 9th of 14 cities and prefectures. Moreover, compared with the advantage data of China in the year of 2013, 7 out of 13 cities and prefectures in the XUAR do not reach the national average of per capita annual income of rural residents, including 4 prefectures in southern Xinjiang with very big gaps respectively.

TABLE 2. Servey of Per-capita annual income of Urban \& Rural residents in Xinjiang and China (2013)

\begin{tabular}{lll}
\hline \hline Area & Urban Residents Rural Residents \\
\hline \hline
\end{tabular}




\begin{tabular}{lcc}
\hline \hline Urumqi City & 21304 & 11496 \\
\hline Karamay City & 25249 & ------- \\
\hline Turpan Prefecture-level City & 11943 & 8170 \\
\hline Hami Prefecture-level City & 20865 & 9908 \\
\hline Changji Hui Autonomous Prefecture & 20111 & 13014 \\
\hline Ili Kazak Autonomous Prefecture & 18496 & 8503 \\
\hline Tacheng Prefecture & 19005 & 11096 \\
\hline Altay Prefecture & 18427 & 7267 \\
\hline Boertala Mongolian Autonomous Prefecture & 18863 & 10636 \\
\hline Bayinguoleng Mongol Autonomous Prefecture & 20408 & 11239 \\
\hline & & \\
\hline Aksu Prefecture & 20049 & 7875 \\
\hline Kirgiz Autonomous Prefecture Xinjiang & 17094 & 3857 \\
\hline Kashgar Prefecture & 15454 & 5393 \\
\hline Hotan Prefecture & $\mathbf{1 8 4 7 8}$ & $\mathbf{4 9 5 1}$ \\
\hline Chinese National Average Data & $\mathbf{2 6 9 5 5}$ & $\mathbf{8 8 9 6}$ \\
\hline \hline
\end{tabular}

Source: Statistic Bureau of Xinjiang Uygur Autonomous Region (SBXUA), 2012

China-Central Asia Relations After the Collapse of the Soviet Union

After the October Revolution broke out in 1917, a number of autonomous republics were set up in Central Asia, which became part of the Soviet Union. So during a very long time, the individual communication between China and the five Central Asian republics should be a part of China-Soviet Union relations. Shortly after the normalization of Sino-Soviet relations in the end of 1980s, the Soviet Union disintegrated and then five Central Asian republics were declared independent. China began to establish and strengthen the cooperation with these Central Asian countries, mainly emphasizing on the solution of border disputes inherited from the Soviet Union era at first. But then with the ChinaCentral Asia relations further boosted, China's multilateral foreign policies towards Central Asia increasingly reflected China's broader economic and security interests in the region through the SCO in particular.

\section{Introduction of the SCO}

Proposed by China and Russia, the SCO was founded in June 2001, with six member states of China, Russia, Kazakhstan, Kyrgyzstan, Tajikistan and Uzbekistan. But it is originated on the basis of "The Shanghai Five", a group originally organized on April 26, 1996, with a primary goal of truststrengthening and disarmament in the border areas.

The total population of all the Member States is 1525 million, or a quarter of the world's population. According to Table 3, in terms of national territory size, Russia ranks the first place with $17,098,242 \mathrm{~km}^{2}$, and China follows it with 9,596,961 $\mathrm{km}^{2}$. Kazakhstan ranks the third place with 2,724,900 $\mathrm{km}^{2}$. However, in terms of national population, China ranks the first place. With the reference of GNI index, Russia and Kazakhstan respectively rank the first and second place, while Kyrgyzstan, Tajikistan and Uzbekistan are relatively backward. From the data below, it is possible to guess that the rapid rise of Kazakhstan can be an important factor to influence the regional stability and development, so is 
the internal bargaining structure of the SCO, which could be one of the challenges that the SCO has to encounter.

TABLE 3. The National conditions of the SCO member states (2014)

\begin{tabular}{ccccc}
\hline \hline Country & $\begin{array}{c}\text { Territory } \\
\mathbf{( k m}^{\mathbf{}} \mathbf{c}\end{array}$ & $\begin{array}{c}\text { Population } \\
\text { (Million) }\end{array}$ & $\begin{array}{c}\text { GDP } \\
\text { (Billion USD) }\end{array}$ & $\begin{array}{c}\text { GNI } \\
\text { (USD) }\end{array}$ \\
\hline China & $9,596,961$ & 1,364 & 10,350 & 7,380 \\
\hline Russia & $17,098,242$ & 143.8 & 1,861 & 13,210 \\
\hline Kazakhstan & $2,724,900$ & 17.29 & 217.9 & 11,670 \\
\hline Kyrgyzstan & 199,951 & 5.834 & 7.404 & 1,250 \\
\hline Tajikistan & 143,100 & 8.296 & 9.242 & 1,060 \\
\hline Uzbekistan & 448,978 & 30.76 & 62.64 & 2,090 \\
\hline \hline Source: Data collected from World Bank data &
\end{tabular}

Source: Data collected from World Bank data

Security cooperation is always the important cornerstone of the SCO. The SCO is one of many international organizations, who clearly put forward the initiative of counter-terrorism. In the initial stages of the SCO, all heads of six member states determined that the objective of defense security cooperation should include the fight against three evil forces----terrorism, separatism and extremism under the guidance of Shanghai Spirit, whose essence is mutual trust, mutual benefit, equality, consultation, respect for diverse civilizations and seeking common development. The operation mechanism of the SCO should contain two parts, the first is meeting mechanism and the other is the permanent body.

There are a series of sessions on the level of Speakers of Parliament, Secretaries of Security Councils, Foreign Ministers, Defense Ministers, Emergency Relief, Economy, Transportation, Culture, Education, Healthcare, Heads of Law Enforcement Agencies, Supreme Courts and Courts of Arbitration, Prosecutors General, apart from the annual Council of Heads of State (CHS) meeting and the Council of Heads of Government (CHG) meeting. The Secretariat in Beijing and the Regional Anti-Terrorism Structure (RATS) in Tashkent are the two permanent bodies of the SCO (Shanghai Cooperation Organization [SCO], 2001). The SCO has run for 15 years since its rename, resulting in a lot of declarations, treaties and agreements. These documents have helped to establish a relatively sound organizational structure and legal system, which effectively ensures the pragmatic cooperation in the fields of security, economy, trade, and culture.

\section{Anti-Terror Cooperation Analysis}

The conception of the SCO joint anti-terror cooperation should be understood in two ways. The first meaning is that the SCO itself attempts to jointly combat terrorism with other countries and organizations in the international community; the second meaning is that the SCO member states jointly strike the three evil forces, namely international terrorism, religious extremism and 
ethnic separatism activated in the great Central Asia region. Here in the paper, author mainly focuses on the second meaning.

Security is the first cooperation direction agreed by the SCO member states, which is related to the international and regional environment at that time. Even now they are still faced with the threats of international terrorism, religious extremism, and ethnic separatism. The Al-Qaeda headquartered in Afghanistan conducted a series of terrorist attacks, which led to the instability of some nations in the great Central Asia, such as the unstable social conditions caused by the East Turkestan Islamic Movement (ETIM) in Xinjiang. The ETIM is one of many terrorist groups keeping touch with the Al-Qaeda. The ETIM gathered a group of ethnic separatists, featured religious extremism to plot and conduct assassinations, kidnappings, bombings and other terrorist subversive sabotages in order to realize their goal of national independence since 1990s. Also the most influential terrorist group in Uzbekistan is the Islamic Movement of Uzbekistan (IMU) and the ILP aiming at spreading Islamic fundamentalism. These two terrorist groups have been considered as radical Islamic organizations whose ultimate goal is to unite other terrorist forces in Tajikistan, Kyrgyzstan, Chechnya and Afghanistan to establish a theocratic Islamic state in the Fergana Valley. In the early 1999, the IMU conducted 6 bombings and attempted to murder Islom Karimov, the president of Uzbekistan. As for the ILP, although it wanted to realize its purpose without using violence at first, it was increasingly radical and further expanded the IMU's momentum.

It is usually very difficult for an individual country to go against the issue of terrorism, if it hopes to achieve a multiplier effect. That's why member states are willing to unite and cooperate through the SCO for keeping the peace and stability in the region. However, the interdependence among states will not seek for cooperation automatically even though they have common interests, as states may fail to cooperate because of distrust, cheating, high costs and potential bad consequences.

The institutional design will help them to cooperate based on the mutual benefits. One of the most important functions of institutional design should be negotiations and bargaining among the related shareholders. In order to reach a collectively-agreed decision, states with comparatively different resources and interests need a degree of regularity in the rules and procedures for their collective decision-making. (Dunne et al., 2013) Article 16 of the SCO Charter has clearly defined the decision-making procedure. All the decisions will be approved by agreement rather than vote. Only if all the member states reach a consensus, the relative decision could be adopted. Some critics say that this decision-making process is rather ineffective on joint cooperation, because consensus is not easy to reach and is also a time-consuming process. However, Article 16(3) regulates that if some member states are not interested in certain cooperation projects but others have interests, the non-participation of these member states does not affect others' willingness in the projects. The flexibility of the negotiation procedures within the SCO makes the possibility of broader cooperation among a part of member states.

TABLE 4. Joint anti-terror drills within the framework of the SCO (2002-2014)

No. Name

Participants (Place) 


\begin{tabular}{|c|c|c|}
\hline 1 & Exercise-01 (2002) & $\begin{array}{l}\text { China, Kyrgyzstan } \\
\text { (Alpine Area of China-Kyrgyzstan Border) }\end{array}$ \\
\hline 2 & Coalition-2003 & $\begin{array}{l}\text { China, Kazakhstan, Kyrgyzstan, Russia, Tajikistan } \\
\text { (Yining city, Ucharal city) }\end{array}$ \\
\hline 3 & Peace Mission-2005 & $\begin{array}{l}\text { China, Russia } \\
\text { (Vladivostok city, Shandong Peninsula, and nearby waters) }\end{array}$ \\
\hline 4 & Tianshan-I (2006) & $\begin{array}{l}\text { China, Kazakhstan } \\
\text { (Almaty province, Yining city) }\end{array}$ \\
\hline 5 & Peace Mission-2007 & $\begin{array}{l}\text { China, Kazakhstan, Kyrgyzstan, Russia, Tajikistan, Uzbekistan } \\
\text { (Urumqi city, Chebarkul city) }\end{array}$ \\
\hline 6 & Peace Mission-2009 & $\begin{array}{l}\text { China, Russia } \\
\text { (Khabarovsk, Taonan Training Base of Shenyang Military Area) }\end{array}$ \\
\hline 7 & Norak-2009 & $\begin{array}{l}\text { China, Kazakhstan, Kyrgyzstan, Russia, Tajikistan } \\
\text { (Norak) }\end{array}$ \\
\hline 8 & Peace Mission-2010 & $\begin{array}{l}\text { China, Kazakhstan, Kyrgyzstan, Russia, Tajikistan } \\
\text { (Almaty province and Matybulak Range) }\end{array}$ \\
\hline 9 & Saratov-2010 & $\begin{array}{l}\text { China, India, Kazakhstan Kyrgyzstan, Mongolia, Pakistan, Russia, } \\
\text { Uzbekistan } \\
\text { International anti-terror institutes } \\
\text { (Saratov region) }\end{array}$ \\
\hline 10 & Peace Mission-2011 & $\begin{array}{l}\text { China, Russia } \\
\text { (Khabarovsk city and a certain area of the Sea of Japan) }\end{array}$ \\
\hline 11 & Tianshan-II (2011) & $\begin{array}{l}\text { China, Kyrgyzstan, Tajikistan } \\
\text { (Kashgar county, Xinjiang) }\end{array}$ \\
\hline 12 & Peace Mission-2012 & $\begin{array}{l}\text { China, Kazakhstan, Kyrgyzstan, Russia, Tajikistan } \\
\text { (Khujand city) }\end{array}$ \\
\hline 13 & Peace Mission-2013 & $\begin{array}{l}\text { China, Russia } \\
\text { (Chelyabinsk) }\end{array}$ \\
\hline 14 & $\begin{array}{l}\text { Kazygurt-Anti-Terror } \\
(2013)\end{array}$ & $\begin{array}{l}\text { Kazakhstan, Kyrgyzstan, Tajikistan } \\
\text { (South Kazakhstan Region) }\end{array}$ \\
\hline 15 & $\begin{array}{l}\text { Border Defense Joint } \\
\text { Determination-2013 }\end{array}$ & $\begin{array}{l}\text { China, Kyrgyzstan } \\
\text { (Border area along China and Kyrgyzstan) }\end{array}$ \\
\hline 16 & Peace Mission-2014 & $\begin{array}{l}\text { China, Kazakhstan, Kyrgyzstan, Russia, Tajikistan } \\
\text { (Inner Mongolia) }\end{array}$ \\
\hline 17 & Oriental - 2014 & $\begin{array}{l}\text { China, Russia } \\
\text { (Manzhouli-Zabaykalsk border port) }\end{array}$ \\
\hline
\end{tabular}

Source: Summarized by author via various internet data

According to Table 4, the military drills within the SCO framework are not always participated by six member states. The SCO member states have organized 17 joint military maneuvers so far. These bilateral and multilateral military exercises have not only enriched the connotation of defense and security cooperation among the SCO member states, but also enhanced the cohesion of the SCO to deter the three evil forces, eventually playing an important role in safeguarding international and regional security and stability.

Currently, the SCO member states made efforts to combat three evil forces in the great Central Asia through joint anti-terror exercises, regular large-scale international information exchange meetings, and the set-up of the joint 
combating internet terrorism working groups and other feasible meeting mechanisms. There are three levels at which the SCO member states attempt to constrain the terror in the region as follows:

Firstly, the SCO has established the legal basis, like member states signed a series of conventions, treaties and agreements related to anti-terror, such as Shanghai Convention on Combating Terrorism, Separatism, and Extremism, Treaty on Combating Illegal Trafficking of Weapons, Ammunition and Explosives, Agreement on the Procedure for Organizing and Conducting Joint Anti-Terrorist Exercise by the Member States of the Shanghai Cooperation Organization, and Counterterrorism Convention of the Shanghai Cooperation Organization (CCSCO). The regulations in the CCSCO well illustrated that the norms within the institution could provide the impetus to have influence on the member states' policies. It explicitly states the connotation and denotation of the "terrorism" and "terrorist act" and offers the clear and basic identified standards of "terrorist organizations". It also regulates the application of scope and principles of the convention as well as the jurisdiction. Moreover, the convention provides the conditions and procedures of the extradition, transfer of sentenced persons and judicial assistance, when terrorists of one state were seized in the other state.

Finnemore (1996) has argued that a major element in the process involves the institution's ability to socialize states, and particular domestic constituents within those states, into global norms. In this way, the domestic political agendas and hence foreign policies of even relatively powerful states can be affected by international institutions (Finnemore, 1996). The SCO should be identified as such an international institution, as its value of the Shanghai Spirit does socialize the member states in dealing with the regional affairs in great Central Asia. The Shanghai Convention on Anti-terror signed by member states has socialized the particular domestic legal system within the member states, as it requires member states to enact related laws on anti-terror. China's top legislature adopted the country's first counter-terrorism law in the latest attempt to address terrorism at home and help maintain world security (National People's Congress (NPC), 2015) on December 27, 2015 according to the article III of the CCSCO, "Member states shall take necessary measures, including enacting domestic legislation when it is appropriate, to punish people who conduct the activities related to the article I (1) above (terrorism, separatism, extremism)."

Secondly, the SCO has formed several agencies and a series of security cooperation mechanisms. The RATS based in Tashkent promotes the establishment of a database on terrorism and boosts the counter-terrorism intelligence cooperation among member states. In addition, the conference mechanisms, like the national security secretary meeting, the defense minister meeting, are formed to facilitate the smooth cooperation on regional security issue, including anti-terror. As Nursultan Nazarbayev, president of Kazakhstan stressed on the tenth anniversary of the SCO, "The SCO has made a significant contribution to the maintenance of international security. Thanks to the effective work of the SCO regional anti-terrorism agencies, more than 500 terrorist incidents have been prevented successfully during 2004 to 2011 (National News 2011). 
The third level is to improve the coordination of member states on combating terrorism by anti-terror exercises. The role of drills can be understood in two perspectives. On one hand, they can deter the aggressive international terrorists, ethnic separatists, and religious extremists and safeguard the peace and stability in the region; on the other hand, they can deepen the trust among the SCO member states, improve the capacity of crack-down of member states' troops and public security institutions, and strengthen the counter-terrorism strategy synergy among participants. Table 4 demonstrates that the joint antiterror drills within the framework of the SCO are organized by member states from 2002 to 2014. There are 17 joint anti-terror exercises with China participating in 16 times. Moreover, 8 exercises were conducted in China and 6 of them launched in the XUAR or along Sino-Central Asia borderline. But the table does not count the joint military cooperation between China and Afghanistan, which is one of the SCO's observer states.

\section{Challenges on Anti-Terror}

The primary purpose of the SCO is to maintain stability in the region, especially jointly anti-terror practices, for creating a good condition for economic development. But with the changes in the current situation in the context of globalization, many new problems have emerged in front of the SCO, in terms of the internal structure and external conditions.

Internal structure contradictions: Firstly, internal pressure. Some member states of the SCO are faced with multiple pressures to maintain domestic stability. If the internal peace has been broken, it will be a good chance for terrorist groups to expand their influence. In Central Asian countries exist many negative issues, like political corruption, economic imbalance, social poverty stemming from the imperfect regimes of market operation, democracy and rule of law, resulting into the serious challenges on domestic stability of some SCO member states. For example, a series of serious riots occurred in Kyrgyzstan on April 7, 2010. Within a few days, the originally firmed regime of President Kurmanbek Bakiyev was ousted almost overnight, while the opposition quickly set up a provisional government and gradually took control of the domestic political situation. This phenomenon can be attributed to the severe economic downturn in Kyrgyzstan. Since the independence, the living conditions of Kyrgyzstan citizen declined significantly. And financial crisis has worsened the dire economic situation in Kyrgyzstan. Besides, due to the geographical and historical reasons, the unbalance of economic development between the northern and southern Kyrgyzstan lasts a very long time, which leads to the long-term North-South conflict. Furthermore, the family-based administration and serious corruption also stir up considerable public discontents.

Secondly, interests coordination: Common interests among the SCO member states are the basis for collaboration and the greatest impetus for its development. There is no doubt that there are a wide range of common interests among the SCO member states. However, each member of the SCO is an independent state with its own particular needs or preferences. Therefore, it is rather important to coordinate the difference from state to state in terms of interests and positions on security issue. If the coordination runs well among member states when dealing with some certain issues, the SCO will gain the power to move forward; if not, the distrust among states will arise and stagnate 
the cooperation. While it is very vital to understand that the interests coordination is not a one-time job, but a regular procedure, as the differences of interests among member states frequently occur in the process of cooperation from time to time. Due to the serious shortage and uneven distribution of water resources in Central Asia, such as Tajikistan, Kyrgyzstan and Uzbekistan, such frictions and disputes happen frequently among the SCO member states, which may lead to the lack of mutual trust and then affect the joint counter-terrorism cooperation.

External conditions: The Afghanistan domestic conflicts and the upheaval in the Middle East have led to the formation of a new wave of Islamic extremism frenzy, posing a serious challenge to security in the great Central Asia.

Afghanistan domestic conflicts: Afghanistan's domestic situation has further deteriorated since Barack Obama, US president announced a gradual drawdown of American forces there. On one hand, the international terrorist forces are very likely to rebound, as US's war on terror has not eradicated the international terrorism thoroughly, but provoked anti-American and antiWestern sentiments in the Islamic world, and also activated the vigor of terrorism forces to some extent. For example, the branches of the Al-Qaeda combined with different geographical characteristics and quickly gathered a large amount of local personnel (jihadists), resulting in a number of new upgraded terrorist groups. The rapid rise of Islamic State of Iraq and Syria (ISIS) since June 2014 should be acknowledged as one of the typical cases. Seen a fragile Afghanistan as a base, international terrorist forces are easy to access to attack the SCO member states. In addition, due to the continuing competition for the leadership of international jihad movement between the newly born ISIS and the old Al-Qaeda, the ISIS decided to allocate 70 million dollars to open up a second front in Central Asia. Meanwhile, some extremist and terrorist forces in Central Asia affected by the ISIS, may also intensify their terrorist attacks here, which formed the new concern of the SCO member states.

Another worried difficulty for the SCO is the resurgence of the Taliban. Because of the Push administration's "War on terror" strategy, the Taliban has suffered miserable losses. However, the Taliban is still the prominent representative of domestic extremism groups in Afghanistan. At present, the Taliban still control several parts of the Afghanistan's territory, mainly in the southern region, whose political stance is extremely stubborn. Since the US government announced the army withdrawal schedule in 2014, the Taliban never concealed their ambition of taking over the Afghanistan's regime. With the US withdrawal schedule proceeding, Taliban forces became resurgent and launched a series of violent attacks. According to a report released by the United Nations on February 2015, there were a total of 10,548 civilian casualties in the Afghanistan domestic conflicts in 2014, including 3699 people found dead and 6849 injured, increased by $22 \%$ compared to the previous year. It is also a year of the largest number of victims since 2009 (United Nation, 2014).

Thereby, after the complete withdrawal of US troops in Afghanistan in 2016 and the cancellation of military assistance and guidance in 2017, the security situation in Afghanistan is not optimistic. Afghanistan authority is confronted with the rebound and infiltration of international terror forces and the counterattack threat of local old terrorist organizations. Once the civil strife gets renewed in Afghanistan, it will give rise to the domestic terrorist activities, drug 
trade and large quantities of weapons expanding to its neighboring countries directly or indirectly, so that the external pressure of the SCO member states will certainly increase.

The upheaval in Middle East: A new wave of Islamic extremist ideological frenzy has formed during the upheaval in the Middle East and diffused to Central Asia, so that member states of the SCO are faced with the arduous task of holding secularization and resisting radical Islam ideology. The local terrorist groups are affected by the Islamic fundamentalism in Great Central Asia including:

(1) IMU. In recent years, due to the success of joint anti-terror drills organized by the SCO member states, the main force of the IMU has gradually moved from the Fergana basin to northern Afghanistan. But the IMU are waiting for an opportunity to return to Uzbekistan. Meanwhile, influenced by the jihad described in the Salafism, one of the extreme Islamic fundamentalism schools, the target of IMU is no longer confined to overthrow the secular government of Uzbekistan, but to respond to the call for global jihad movement. Furthermore, the revival of the Taliban forces in the region will easily provoke the offensive religious extremism forces, like the IMU. The reality is that such activity has been found in Badakhshan, Kunduz and Badghis provinces in northern Afghanistan.

(2) Jund al-Khilafah, founded in summer 2011, is a terrorist group identified by the Kazakhstan authority. Influenced by the Salafism, this group launched a series of terrorist attacks in Kazakhstan and claimed that it desired to overthrow the apostate, Nursultan Nazarbayev administration for the establishment of Islamic Caliphate regime in Kazakhstan.

(3) The ILP. It was founded in Palestine in 1953 with the Salafist doctrine as the dominant ideology. It initially emerged in Uzbekistan and gradually extended to other states in the great Central Asia after the collapse of the Soviet Union. Most recently, the ILP took the chance to recruit in Kyrgyzstan after the 2010 South Kyrgyzstan ethnic clashes between ethnic Kyrgyz and Uzbeks. The ILP further expanded rapidly in Central Asia, even penetrating into the southern region of Kazakhstan. The authorities of Kazakhstan and Kyrgyzstan arrested several batches of the ILP members carrying religious extremism propaganda materials.

(4) Turkistan Islamic Party (TIP). The TIP was founded in 2008, identified as a Uyghur extreme terrorist group active in the border area of Afghanistan and Pakistan by China. It is the third-largest terrorist group in the great Central Asia at present that attempts to bring "Xinjiang Independence Movement" and other terror activities into the global jihad movement. The TIP equates its jihad acts against Chinese government with the jihad movements in Iraq and Afghanistan. As Institute of International Relations, Renmin University of China (2015) Yuanzheng believe, "Several violent terrorist incidents occurred successively in Xinjiang recently with certain new features. For examples, the planers and conductors of terrorist attacks have watched the audio and video materials related to the ETIM or TIP. They are eager for launching jihad so that their preparation time is rather short, but they seek for high causalities....Both nonIslamic believers and "hypocritical" Islamic followers are their targets. Besides, they are directly affected by the propaganda of global jihad movement and are ready to participate in Syria's domestic conflicts (Chen \& Li, 2015)." Clearly, 
what happens in Xinjiang is closely related to the instability in the Middle East and Afghanistan.

\section{CONCLUSION}

"Chun Wang Chi Han(唇亡齿寒)", a Chinese idiom, literally means that "With lips gone, teeth are exposed to cold", which describes an interdependence relation. Author believes that it is quite appropriate to use this idiom to represent the political and economic connections between Xinjiang region of China and Central Asia. In such an environment of anarchy, the cross-border cooperation among states, the major actors in international relations, should be considered as the good way to solve transnational problems. Therefore, in order to settle the Xinjiang Uighur Muslim unrests, the affinities between China and Central Asian countries will affect the final solution to the issue, except for China's domestic policies coordination.

After the establishment of the PRC in the year of 1949, the East Turkestan separatists influenced by the Pan-Islamism and Pan-Turkism, conducted a lot of violent attacks with the support of the Soviet Union. At that time, even though the PRC was allied with the Soviet Union, such unrest cannot be avoided as the actual influence of the Soviet Union in Xinjiang was quite deep. As author observed, the Sino-Soviet relation was not equal during the first decade since the PRC was founded. In perspectives of then Soviet Union leaders, China was more like an actual Kazakhstan-style republic, or at least Xinjiang region of China was similar to the Kazakhstan-style republic. That's why the "Xinjiang Independence" was less active before the year of 1959. Since 1960s, the SinoSoviet relation turned to be hostile so that the East Turkestan forces came back to life again with funds, weapons and training centers provided by the Soviet Union. Not until the end of 1980s, the relations between China and the Soviet were still unfriendly, leaving many disputes in terms of border, Marxism ideologies, Afghanistan etc. During this period, the Xinjiang Uyghur Muslim riots still occurred but the number and scale were relatively reduced, as the Soviet Union was busy in competing with the US, the other hegemony in the anarchy world.

After the collapse of the Soviet Union in the early 1990s, China established diplomatic relations with those Central Asian republics in the first time, aiming at building up friendly bilateral relations to maintain the regional peace. During the past 25 years of relative peaceful period, the relations between China and Central Asian states should be divided into three phases: (1) From December 1991 to September 1997: The good-neighborly and friendly relations phase; (2) From September 1997 to June 2001: The closer cooperation on energy, trade and security phase; and (3) From June 2001 to now: The all-round bilateral and multilateral (The SCO) cooperation phase.

Currently, the relations between China and Central Asian states are closer and better than before in terms of security and economic cooperation in particular. The joint efforts to counter three evil forces in Xinjiang and Central Asia make the scale and frequency of those terror cases here to shrink. But these East Turkestan forces still attempt to gain the support of western society, try to instigate the relation between Uyghurs and Han people in all sorts of ways and lure a part of Muslims to immigrate illegally to join in the jihad. As the strike-hard campaigns in China and the closer cooperation between China and 
Central Asia states via the SCO, a small part of terrorists prefers to illegally travel from southern provinces of China to Southeast Asia as a transfer station, to Turkey, or further go to fight in the frontline of Syria and Afghanistan rather than escaping from Xinjiang to Central Asia for jihad directly. This can be seen as another proof of the achievement of the good Sino-Central Asia relation on the constraint of Xinjiang Uyghur Muslim riots. However, the resurgence of Xinjiang Uyghur Muslim riots in 1990s could not be separately analyzed, thanks to the influence of the changes in the pattern of international relations and the Islamic renaissance movements in West Asia and North Africa.

With the changes in the current situation in the context of globalization, many new problems have emerged in front of the SCO to counter three evil forces, in terms of the internal structure and external conditions. Domestic pressure within the member states and interests coordination among member states are identified as the main internal challenges that may affect the constraint of three evil forces in Central Asia. Afghanistan domestic conflicts and the upheaval in the Middle East also pose critical external obstacles to the peaceful coexistence of China and Central Asia. How to react appropriately to those old and new threats is what the SCO has to consider and research for such a long time. In this sense, China and Central Asia will continue deepening their closer cooperation to counter three evil forces within the framework of the SCO and attempt to coordinate shareholders' interests based on the Shanghai Spirit.

\section{REFERENCES}

Bellér-Hann, Ildikó. 2007. Situating the Uyghurs between China and Central Asia: 37-41. Farnham, UK: Ashgate Publishing Company.

Cartalucci, Tony. 2015. China's Xinjiang problem-Made in USA. New Eastern Outlook, URL: http://goo.gl/3uHuUI (accessed on October 10, 2015)

Chinanews.com. (2011). President of Kazakhstan speaks on the 10th anniversary of the SCO. Xinhua News. URL: http://goo.gl/5FqgqH (accessed April 26, 2015).

Dunne, Tim, Milja Kurki, and Steve Smith. 2013. International relations theories: Discipline and diversity: 121-129. 3rd ed. Oxford, UK: Oxford University Press,

Finnemore, Martha. 1996. National interests and international society. New York, US: Cornell University Press.

Forbes, Andrew D.W. 1986. Warlords and Muslims in Chinese Central Asia: A political history of Republican Sinkiang. Cambridge, UK: Cambridge University Press.

Global Times. 2015. Some Uyghurs travel to Turkey to connect with local culture, religion, but fail to find what they hoped. Phoenix Weekly. URL: http://goo.gl/99UxiB (accessed April 26, 2016).

He, W.M. \& Wang, T.Z. (Eds.). (2001). Zhongguo Minzu (Chinese Nationalities). Minzu University of China Press.

Information Office of the State Council of the People's Republic of China [IOSCPRC]. 2003. White paper on history, development of Xinjiang. Beijing, China. URL: http://goo.gl/l3ZBSx (accessed April 27, 2016).

Institute of International Relations, Renmin University of China. 2015. Challenges and solutions of the member states of Shanghai cooperation organization in the context of the withdrawal of us force in Afghanistan. Contemporary Internal Relations. URL: http://d.wanfangdata.com.cn/periodical/xdgjgx201503004 (accessed April 27, 2016).

Kadeer, Rebiya, and Alexandra Cavelius. 2009. Dragon fighter: One woman's Epic struggle for peace with China: 9-13. Carlsbad, CA: Kale Press.

Lai, Hongyi H. 2002. China's western development program: Its rationale, implementation, and prospects. Modern China 28, no. 4: 432-466. DOI: 10.1177/009770040202800402

McGovern, J. (2009). H.RES. 953. Resolution. Paper Presented at the 1st Session of the 111th Congress, US. URL: https://www.govtrack.us/congress/bills/111/hres953/text (accessed on December 15, 2015). 
McMillan, Ann. 2009. Xinjiang and Central Asia: Independency, not integration. In China, Xinjiang and Central Asia: History, transition and crossborder interaction into the $21^{\text {st }}$ century, eds. Colin Mackerras, Michael Clarke, London, UK: Routledge.

Millward, James A., and Peter C. Perdue. 2004. Political and cultural history of the Xinjiang region through the late nineteenth century. In Xinjiang: China's Muslim borderland, ed. S. Frederick Starr. Armonk, NY: Sharpe.

National News. 2011. President of Kazakhstan, the author talk about the tenth anniversary of the SCO. URL: https://goo.gl/EyTclD (accessed on 15 February 2016).

National People's Congress (NPC). 2015. China adopts first counter-terrorism law in history. Xinhua News. URL: http://goo.gl/qBQ3nQ (accessed on December 27, 2015).

News Week. (2009). Wurumuqi "7-5 Shijian" Qianzhuan: Xinjiangdaxue Baoweizhan (The Prequel of July 2009 Urumqi Riots: The "Defending War" of Xinjiang University). URL: http://goo.gl/XEfVPx (accessed on December 15, 2015).

Shan, Wei, and Weng Cuifen. 2010. China's new policy in Xinjiang and its challenges. East Asian Policy 2, no. 3: 58-66.

Shanghai Cooperation Organization. 2001. Brief introduction to the Shanghai cooperation organization. URL: http://goo.gl/6YTOSM (accessed April 25, 2016).

Starr, S. Frederick. (Eds.). 2004. Xinjiang: China's Muslim Borderland: 138-140. Central Asia-Caucasus Institute, Washington, DC., US.

Statistic Bureau of Xinjiang Uygur Autonomous Region. 2012. Xinjiang statistical yearbook 2012. Beijing, China: China Statistics Press.

Statistic Bureau of Xinjiang Uygur Autonomous Region. 2014. Xinjiang statistical yearbook 2014. Beijing, China: China Statistics Press.

Tukmadiyeva, Malika. 2013. Xinjiang in China's foreign policy toward Central Asia. The Quarterly Journal 12, no. 3: 87110. DOI: $10.11610 /$ connections.12.3.05

United Nation. 2014. In Afghanistan's deadliest year, civilian casualties top 10,000 in 2014 -UN. UN News Center. URL: http://goo.gl/Uueemr (accessed on 18 February 2016).

Wendt, Alexander.1999. Social theory of international politics. Cambridge, UK: Cambridge University Press. DoI: $10.1017 / \mathrm{CBO} 9780511612183$

World Bank. n.d. Data by countries and economies. URL: http://data.worldbank.org/country (accessed on December $15,2015)$

Zhao, Huasheng. 2007. Central Asia in China's diplomacy. In Central Asia: The view from Washington, Moscow, and Beijing: 54, eds. Rumer, B. Eugene, Dmitrĭ̌ Trenin, and Huasheng Zhao. New York, NY: M. E. Sharpe.

— This article does not have any appendix. - 